Check for updates

Cite this: RSC Adv., 2018, 8, 1022

Received 26th September 2017 Accepted 11th December 2017

DOI: 10.1039/c7ra10632g

rsc.li/rsc-advances

\section{Enhanced thermal conductivity in a hydrated salt PCM system with reduced graphene oxide aqueous dispersion}

\author{
Xinxing Zhang, (DD abc Xiang Li, ${ }^{\text {ac }}$ Yuan Zhou, ${ }^{\text {*ac }}$ Chunxi Hai, (D) ac Yue Shen, ${ }^{\text {ac }}$ \\ Xiufeng Ren ${ }^{\text {ac }}$ and Jinbo Zeng ${ }^{\text {ac }}$
}

The phase change enthalpy, thermal conductivity, thermal stability and thermal reliability of a novel reduced graphene oxide ( $r-\mathrm{GO}$ ) containing phase change material (PCM) $r-\mathrm{GO} / \mathrm{CaCl}_{2} \cdot 6 \mathrm{H}_{2} \mathrm{O}$ were investigated. The material was made by the aqueous dispersion of $r-\mathrm{GO}$ and calcium chloride dihydrate $\left(\mathrm{CaCl}_{2} \cdot 2 \mathrm{H}_{2} \mathrm{O}\right)$ according to the mass ratio of $\mathrm{CaCl}_{2}$ and crystal water in $\mathrm{CaCl}_{2} \cdot 6 \mathrm{H}_{2} \mathrm{O}$. The thermal conductivity of the phase change material increased by $\sim 80 \%$ when using $\sim 0.018 \%$ (by weight) of $r$-GO with a $\sim 2.7 \%$ decrease of enthalpy (i.e., storage capacity), while using $\sim 0.018 \%$ of graphite led to an increase of thermal conductivity by $\sim 14 \%$ and a decrease of enthalpy by $\sim 5.6 \%$. Additionally, the surface active agent for dispersing $\mathrm{r}-\mathrm{GO}$ had the extra function of enhancing the system stability and reliability. The decomposing temperatures of $r-\mathrm{GO} / \mathrm{CaCl}_{2} \cdot 6 \mathrm{H}_{2} \mathrm{O}$ were higher than those of $\mathrm{CaCl}_{2} \cdot 6 \mathrm{H}_{2} \mathrm{O}$. After 100 cycles, the melting and crystallizing enthalpies of $r-\mathrm{GO} / \mathrm{CaCl}_{2} \cdot 6 \mathrm{H}_{2} \mathrm{O}$ decreased to $178.4 \mathrm{~J} \mathrm{~g}^{-1}$ and $150.7 \mathrm{~J} \mathrm{~g}^{-1}$ from $180.6 \mathrm{~J} \mathrm{~g}^{-1}$ and $153.7 \mathrm{~J} \mathrm{~g}^{-1}$, dropping by $1.2 \%$ and $2.0 \%$, respectively, while for $\mathrm{CaCl}_{2} \cdot 6 \mathrm{H}_{2} \mathrm{O}$ they decreased to $178.9 \mathrm{~J} \mathrm{~g}^{-1}$ and $147.8 \mathrm{~J} \mathrm{~g}^{-1}$ from $185.6 \mathrm{~J} \mathrm{~g}^{-1}$ and $161.8 \mathrm{~J} \mathrm{~g}^{-1}$, dropping by $3.7 \%$ and $8.7 \%$, respectively. The thermal conductivity enhancement of $\mathrm{CaCl}_{2} \cdot 6 \mathrm{H}_{2} \mathrm{O}$ with r-GO was markedly superior compared to that with graphite and other thermal conductive additives reported in previous literature, and the provided method (i.e., preparing aqueous dispersions of additives firstly and synthesizing hydrated salt PCMs with corresponding salts subsequently) was also applicable for other functional additives that cannot be directly dispersed well to modify the thermal properties of hydrated salt PCM systems.

\section{Introduction}

Thermal energy is one of the major forms of energy in the universe, and exists in sources such as solar radiation, natural geothermal energy and oceans in the natural environment. Additionally, it is released as waste heat in the production and operation systems of human society, from artificial facilities such as metal smelting systems, heating systems of buildings and various machines. There is great interest in the development of highly efficient transfer and conversion systems as well as materials to transfer the energy or convert it into other forms of energy such as electricity. ${ }^{\mathbf{1}, 2}$ Phase change materials (PCMs), possessing the ability to absorb and release energy in the process of changing phase, have drawn a lot of attention due to

${ }^{a}$ Key Laboratory of Comprehensive and Highly Efficient Utilization of Salt Lake Resources, Qinghai Institute of Salt Lakes, Chinese Academy of Sciences, Xining 810008, China. E-mail: lixiang@isl.ac.cn; zhouy@isl.ac.cn; Fax: +86 971 6338403; Tel: +869716338403

${ }^{b}$ University of Chinese Academy of Sciences, Beijing, 100049, China

${ }^{c}$ Key Laboratory of Salt Lake Resources Chemistry of Qinghai Province, Xining, 810008, China their high latent heat in applications..$^{3-6}$ One important type is the hydrated salt PCM, which has been a study hotspot in the field of low temperature due to distinct advantages such as high heat fusion, low price, and high security in energy storage systems. ${ }^{7}$ They can be utilized as thermal functional materials for thermal control of buildings, ${ }^{8}$ air conditioning systems ${ }^{9}$ and solar energy. ${ }^{10}$ However, a major defect is their low thermal conductivity which increases the temperature gradients and time constants as well as reduces heat transfer rates. Therefore, modifying the property of thermal conductivity is a critical problem in hydrated salt PCMs. ${ }^{\mathbf{1 1 , 1 2}}$ To achieve this goal, many methods have been used including impregnating PCMs into a high thermal conductivity matrix ${ }^{\mathbf{1 3}}$ and adding high conductivity fillers such as oxidation expandable graphite, ${ }^{\mathbf{1 4}}$ nanocopper, ${ }^{15}$ nano- $\mathrm{Al}_{2} \mathrm{O}_{3}$ (ref. 16) and graphite flakes. ${ }^{17}$ Excellent results have been obtained in those works. It is natural that additives with higher thermal conductivity will boost larger thermal conductivity enhancement in PCMs while allowing a smaller quantity of additive to be used, which further leads to a smaller reduction of phase change enthalpy.

Graphene, a honeycomb-structured sheet of carbon atoms, possesses excellent properties including high thermal 
conductivity. The thermal conductivity of single layer graphene can reach as high as $5300 \mathrm{~W} \mathrm{~m}{ }^{-1} \mathrm{~K}^{-1} \cdot{ }^{18}$ Therefore, it has the potential to be an ideal material for modifying the thermal conductivity of PCMs. However, dispersing graphene directly into hydrated salts is difficult due to its easy agglomeration caused by the Van Edward force between the carbon layers and hydrophobicity. ${ }^{19}$ Graphene oxide (GO) including oxygencontaining functional groups on the surface has a good dispersibility in aqueous dispersions. ${ }^{20}$ However, its thermal conductivity is reduced because of structural defects. To overcome this drawback and keep good dispersivity simultaneously, the method is to reduce the aqueous dispersion of GO to the aqueous dispersion of r-GO which possesses good dispersivity and better thermal conductivity due to the reparation of structural defects. $^{21,22}$ The aqueous dispersion of r-GO with good dispersivity can be utilized directly to synthesize hydrated salts using corresponding salts according to the mass ratio of the salt and crystal water in hydrated salt PCMs. Additionally, it is reported that r-GO can be used to improve thermal conductivity of materials such as polystyrene, ${ }^{23}$ polyimide $^{24}$ and paper. $^{25}$ Therefore, the aqueous dispersion of r-GO could be a promising candidate to enhance the thermal conductivity of hydrated salt PCMs.

Therefore, GO was made using a modified Hummers' method and further reduced to make a stable r-GO aqueous dispersion using the reducing agent hydrazine hydrate and the surface active agent polyvinyl pyrrolidone (PVP). According to the mass ratio of calcium chloride and crystal water in calcium chloride hexahydrate $\left(\mathrm{CaCl}_{2} \cdot 6 \mathrm{H}_{2} \mathrm{O}\right)$, calcium chloride dihydrate $\left(\mathrm{CaCl}_{2} \cdot 2 \mathrm{H}_{2} \mathrm{O}\right)$ was added into the r-GO aqueous dispersion to make the r-GO/CaCl $2 \cdot 6 \mathrm{H}_{2} \mathrm{O} \mathrm{PCM}$, and the graphite (G)/ $\mathrm{CaCl}_{2} \cdot 6 \mathrm{H}_{2} \mathrm{O}$ PCM was also made in order to make a comparison of the boosting effect on the thermal conductivity between r-GO and graphite. A series of thermal properties was tested. It is significant that the improvement of the thermal conductivity should be achieved by sacrificing enthalpy as little as possible. The results in this work show that the r-GO aqueous dispersion causes a large increase in the thermal conductivity of PCMs with a small reduction of enthalpy, which is superior to graphite and other additives such as nano$\mathrm{Al}_{2} \mathrm{O}_{3}$, nano-Cu and graphite flakes in the previous studies, and the method (i.e., preparing aqueous dispersions of additives firstly and synthesizing hydrated salt PCMs with corresponding salts subsequently) is also a promising way for other additives that cannot be directly dispersed well in hydrated salt PCM systems to modify thermal properties. Additionally, the active agent PVP used for dispersing r-GO has extra functions to enhance the stability and reliability of hydrated salts. In this work, the new system of the r-GO/ $\mathrm{CaCl}_{2} \cdot 6 \mathrm{H}_{2} \mathrm{O}$ PCM was prepared with $\mathrm{r}-\mathrm{GO}$ aqueous dispersion to effectively enhance the thermal conductivity by means of firstly preparing aqueous dispersions of additives, and secondly synthesizing hydrated salt PCMs with corresponding salts. Meanwhile, other phase change behaviors such as the supercooling degree, phase change temperature, latent heat, thermal stability and reliability of the PCM in the presence of r-GO were also studied.

\section{Experimental section}

\subsection{Materials}

Graphite powder (C, high dispersivity) was purchased from Yuandong oil refinery company, China. Potassium persulfate $\left(\mathrm{K}_{2} \mathrm{~S}_{2} \mathrm{O}_{8}\right.$, analytically pure), potassium permanganate $\left(\mathrm{KMnO}_{4}\right.$, guarantee reagent), sulphuric acid $\left(\mathrm{H}_{2} \mathrm{SO}_{4}, 98 \%\right)$, hydrochloric acid ( $\mathrm{HCl}$, analytically pure), hydrogen peroxide $\left(\mathrm{H}_{2} \mathrm{O}_{2}\right.$, guaranteed reagent), hydrazine hydrate $\left(\mathrm{N}_{2} \mathrm{H}_{4}\right.$, analytically pure) and calcium chloride dihydrate $\left(\mathrm{CaCl}_{2} \cdot 2 \mathrm{H}_{2} \mathrm{O}\right.$, analytically pure) were purchased from Sinopharm Chemical Reagent company, China. Phosphorus pentoxide $\left(\mathrm{P}_{2} \mathrm{O}_{5}\right.$, analytically pure) was purchased from China pharmaceutical company, China. Polyvinyl pyrrolidone (average mol wt 10 000) was supplied by Sigma-Aldrich company, America.

\subsection{Preparation of additives, aqueous dispersions and PCMs}

GO was made from graphite powder following a modified Hummers' method. ${ }^{26,27}$ Firstly, $\mathrm{K}_{2} \mathrm{~S}_{2} \mathrm{O}_{8}(8 \mathrm{~g}), \mathrm{P}_{2} \mathrm{O}_{5}(8 \mathrm{~g})$ and $\mathrm{H}_{2} \mathrm{SO}_{4}(25 \mathrm{~mL}, 98 \%)$ were mixed well before $\mathrm{C}(5 \mathrm{~g})$ was added into a round bottom flask. Subsequently, the mixture was reacted in a water bath $\left(80^{\circ} \mathrm{C}\right)$ for $5 \mathrm{~h}$. The reaction liquid was diluted to $500 \mathrm{~mL}$ with deionized water and left to set for $12 \mathrm{~h}$. The sediment and liquid components were separated, and the sediment was dried at $45{ }^{\circ} \mathrm{C}$ for 2 days. Secondly, the sediment $(2 \mathrm{~g})$ was added into $\mathrm{H}_{2} \mathrm{SO}_{4}(150 \mathrm{~mL})$ in a water bath $\left(0{ }^{\circ} \mathrm{C}\right)$, then $\mathrm{KMnO}_{4}(25 \mathrm{~g})$ was added to the reaction which was placed in the water bath $\left(35^{\circ} \mathrm{C}\right)$ for $4 \mathrm{~h}$ before deionized water $(250 \mathrm{~mL})$ was added. When the temperature of the mixture fell below $50{ }^{\circ} \mathrm{C}$, $\mathrm{H}_{2} \mathrm{O}_{2}(30 \mathrm{~mL}, 30 \%)$ was added to the mixture to stop the reaction after deionized water $(1 \mathrm{~L})$ was added. The obtained mixture was left to set for $2 \mathrm{~h}$ and solid GO was obtained through filtration. Further purification methods were used including washing the solid twice with deionized water $(1 \mathrm{~L})$ after it was washed with $\mathrm{HCl}(1 \mathrm{~L}, 4 \%)$, and being further dialyzed for 3-5 days. Finally, the GO sample was used to prepare a $2 \mathrm{mg} \mathrm{mL} \mathrm{m}^{-1}$ aqueous dispersion by means of ultrasound for $2 \mathrm{~h}$.

Hydrazine hydrate $\left(M_{1}, 0.4 \mathrm{~g}, \mathrm{~N}_{2} \mathrm{H}_{4}, 54.4 \%\right)$ and PVP $\left(M_{2}, 4.0\right.$ $\mathrm{g})$ were added into the $\mathrm{GO}$ aqueous dispersion $(20 \mathrm{~mL})$ and stirred for $30 \mathrm{~min}$. The dispersion mixture then went through an isothermal reaction in a reactor at $90{ }^{\circ} \mathrm{C}$ for $2 \mathrm{~h}$, and the obtained r-GO aqueous dispersion was diluted to $70 \mathrm{~mL}(3.5$ fold dilution) and sonicated for $30 \mathrm{~min}$. The weight of the mixture $\left(M_{3}\right)$ was measured using a high precision balance. Then the weight of the water $\left(M_{4}\right)$ in the r-GO aqueous dispersion was calculated using the formula $M_{4}=M_{3}-M_{1} \times 54.4 \%-$ $M_{2}$. Finally, according to the stoichiometric ratio of calcium chloride and crystal water in $\mathrm{CaCl}_{2} \cdot 6 \mathrm{H}_{2} \mathrm{O}, \mathrm{CaCl}_{2} \cdot 2 \mathrm{H}_{2} \mathrm{O}$ $\left(2.045 M_{4}\right)$ was added into the aqueous dispersion of r-GO to prepare $\mathrm{CaCl}_{2} \cdot 6 \mathrm{H}_{2} \mathrm{O}$ with the first step of stirring for $5 \mathrm{~min}$ and the second step of a $30 \mathrm{~min}$ ultrasound. The principle of the preparation of the $\mathrm{r}-\mathrm{GO} / \mathrm{CaCl}_{2} \cdot 6 \mathrm{H}_{2} \mathrm{O} \mathrm{PCM}$ is shown in Fig. 1. The average volume and surface area sizes of the graphite (G) particles are $9.103 \mu \mathrm{m}$ and $4.607 \mu \mathrm{m}$, respectively. The $\mathrm{G}$ aqueous dispersion $\left(2 \mathrm{mg} \mathrm{mL}{ }^{-1}\right.$ ) was made by ultrasound first, 


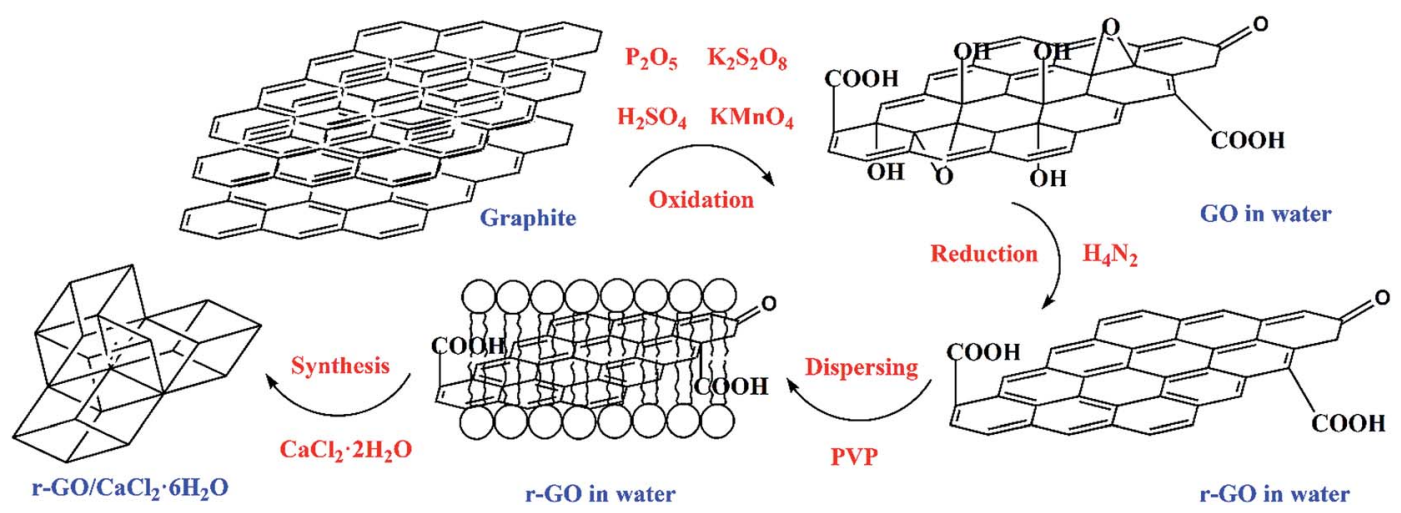

Fig. 1 The preparation principle of the $\mathrm{r}-\mathrm{GO} / \mathrm{CaCl}_{2} \cdot 6 \mathrm{H}_{2} \mathrm{O} P C M$.

and the $\mathrm{G} / \mathrm{CaCl}_{2} \cdot 6 \mathrm{H}_{2} \mathrm{O}$ PCM was made by following the same steps as those for the r-GO/CaCl${ }_{2} \cdot 6 \mathrm{H}_{2} \mathrm{O}$ PCM without the step of the reduction reaction.

\subsection{Characterization}

The particle size distribution was detected by a laser particle size analyzer (Mastersizer 2000). The UV spectra were measured using a UV-Vis spectrophotometer (PerkinElmer Lambda750) with wavenumber ranging from 200 to $800 \mathrm{~nm}$. The Raman spectra were measured by a micro-Raman spectrometer (DXR) with a $532 \mathrm{~nm}$ laser. The crystalline phases of the samples were measured using X-ray diffraction (X'PRO Pert). Thermal conductivities were obtained from a thermal conductivity tester (HDRX3A) at $30^{\circ} \mathrm{C}$. The thermal properties were measured by using differential scanning calorimetry (DSC, TA Q20), where the samples were sealed in an alumina pan in a purified nitrogen atmosphere. The viscosity was tested using a Digital Viscometer (NDJ-8S) (testing range: $1-2 \times 10^{6}$ mpa s) with $30 \mathrm{rpm}$ at $22^{\circ} \mathrm{C}$. Thermal stability testing was performed simultaneously using DSC-TGA (Q600), where samples were heated from $25{ }^{\circ} \mathrm{C}$ to $500{ }^{\circ} \mathrm{C}$ at a rate of $5{ }^{\circ} \mathrm{C} \mathrm{min}^{-1}$ under a nitrogen atmosphere. The estimated uncertainties are listed in Table 1.

\section{Results and discussion}

\subsection{Characterization of GO and r-GO}

The reduction of graphene oxide is characterized by the color changing from brown ( $\mathrm{GO}$ ) to black (r-GO) as shown in the inset of Fig. 2(a). The recovery of the black color in r-GO indicates the re-graphitization of GO due to the removal of oxygen-containing functional groups. Fig. 2(a) shows that the peak in the UV spectrum of GO appears at $230 \mathrm{~nm}$ due to the $\pi-\pi^{*}$ transition of

Table 1 The estimated uncertainties of the measurements

\begin{tabular}{ll}
\hline Property & Estimated uncertainty \\
\hline Mass & $0.12 \mathrm{mg}$ \\
Temperature (DSC) & $0.058-0.58{ }^{\circ} \mathrm{C}$ \\
Latent enthalpy & 0.0012 \\
Thermal conductivity & 0.058
\end{tabular}

aromatic $\mathrm{C}=\mathrm{C}$ bonds, ${ }^{28}$ while the peak is red shifted to $268 \mathrm{~nm}$ in the spectrum of r-GO, which is attributed to the enhancement of electron concentration and structural ordering as well as the increased linking model of the $\mathrm{sp}^{2}$ carbon atoms. ${ }^{29}$ This characterizes the restoration of the graphene structure in r-GO.

It has been reported that Raman spectroscopy can study disorders and defects in the crystal structures of graphite and its derivatives, and disorder can be investigated using the intensity ratio of the disorder induced $\mathrm{D}$ band and the Raman allowed $\mathrm{G}$ band $\left(I_{\mathrm{D}} / I_{\mathrm{G}}\right)$. In Fig. $2(\mathrm{~b})$, the Raman spectra show that the $\mathrm{G}$ band appears at $1612 \mathrm{~cm}^{-1}$ and $1605 \mathrm{~cm}^{-1}$, whereas the $\mathrm{D}$ band is at $1347 \mathrm{~cm}^{-1}$ and $1346 \mathrm{~cm}^{-1}$ for GO and r-GO, respectively. It has been reported that the $\mathrm{G}$ band is caused by the $\mathrm{C}-\mathrm{C}$ bond stretch of $\mathrm{sp}^{2}$ carbon $^{30}$ and originates from the first order Raman scattering. ${ }^{31}$ In this work, the G band of r-GO is shifted to a lower wavenumber because of the increasing number of $\mathrm{sp}^{2}$ carbon atoms, and the $I_{\mathrm{D}} / I_{\mathrm{G}}$ is 1.12 (for r-GO) compared to 0.93 (for $\mathrm{GO}$ ), which agrees with the previous results, ${ }^{32}$ indicating an increase in conjugated carbon atoms followed by the removal of oxygen containing groups in r-GO. These characterizations prove that the reduction of GO has been achieved by the method in this work.

\subsection{The dispersing stabilities of additives in aqueous solutions and PCMs}

The dispersivity of additives is the key factor to guarantee thermal conductivity enhancement in PCMs. Fig. 3 shows the stability of r-GO and $\mathrm{G}$ aqueous dispersions over six months. The result indicates that both of the aqueous dispersions keep good stability in the testing, which is attributed to the function of the surface active agent (PVP). Additionally, Fig. 4 demonstrates that the $\mathrm{r}-\mathrm{GO}$ in $\mathrm{r}-\mathrm{GO} / \mathrm{CaCl}_{2} \cdot 6 \mathrm{H}_{2} \mathrm{O}$ and the $\mathrm{G}$ in $\mathrm{G} /$ $\mathrm{CaCl}_{2} \cdot 6 \mathrm{H}_{2} \mathrm{O}$ have good dispersivities over a test period of four months. These stable dispersivities of additives can cause good performance on boosting the thermal conductivities of hydrated salt PCMs.

\subsection{Material identification of PCMs}

$\mathrm{CaCl}_{2}$ has two other kinds of hydrated salt form which are $\mathrm{CaCl}_{2} \cdot 4 \mathrm{H}_{2} \mathrm{O}$ and $\mathrm{CaCl}_{2} \cdot 2 \mathrm{H}_{2} \mathrm{O}$, and it is necessary to establish the existence of the structure of $\mathrm{CaCl}_{2} \cdot 6 \mathrm{H}_{2} \mathrm{O}$ when other 

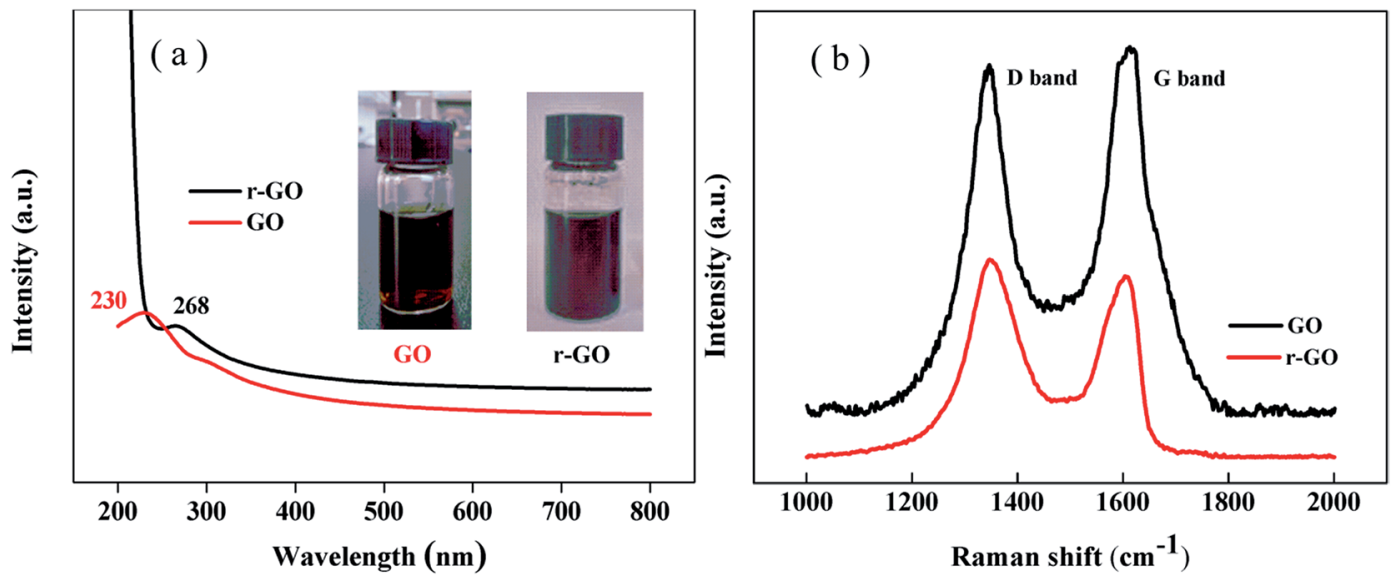

Fig. 2 (a) The UV and (b) Raman spectra of GO and r-GO.

components are combined with it to make composite PCMs. The XRD patterns of $\mathrm{G} / \mathrm{CaCl}_{2} \cdot 6 \mathrm{H}_{2} \mathrm{O}, \mathrm{r}-\mathrm{GO} / \mathrm{CaCl}_{2} \cdot 6 \mathrm{H}_{2} \mathrm{O}$ and the standard card of $\mathrm{CaCl}_{2} \cdot 6 \mathrm{H}_{2} \mathrm{O}$ are shown in Fig. 5. All of the characteristic peaks of $\mathrm{r}-\mathrm{GO} / \mathrm{CaCl}_{2} \cdot 6 \mathrm{H}_{2} \mathrm{O}$ and $\mathrm{G} / \mathrm{CaCl}_{2} \cdot 6 \mathrm{H}_{2} \mathrm{O}$ are consistent with the peaks of the standard card of $\mathrm{CaCl}_{2} \cdot 6 \mathrm{H}_{2} \mathrm{O}$, which illustrates that the method of combination of $\mathrm{CaCl}_{2}$ $\cdot 2 \mathrm{H}_{2} \mathrm{O}$ and the aqueous dispersions of additives can make a composite PCM of $\mathrm{CaCl}_{2} \cdot 6 \mathrm{H}_{2} \mathrm{O}$, and the dispersing $\mathrm{G}, \mathrm{r}-\mathrm{GO}$ and PVP do not affect the formation of the crystal phase of $\mathrm{CaCl}_{2} \cdot 6 \mathrm{H}_{2} \mathrm{O}$. This demonstrates the function of $\mathrm{G} / \mathrm{CaCl}_{2} \cdot 6 \mathrm{H}_{2} \mathrm{O}$ and $\mathrm{r}-\mathrm{GO} / \mathrm{CaCl}_{2} \cdot 6 \mathrm{H}_{2} \mathrm{O}$ as phase change materials in practical applications.

\subsection{The thermal conductivities of PCMs}

The rate of energy storage and release is an important property in thermal storage systems, and it depends on the thermal conductivity of the phase change materials. The thermal conductivities of samples were measured at $30{ }^{\circ} \mathrm{C}$ by the transient hot-wire method and the results are presented in Fig. 6 . The thermal conductivity of $\mathrm{CaCl}_{2} \cdot 6 \mathrm{H}_{2} \mathrm{O}$ is $0.56 \mathrm{~W} \mathrm{~m}{ }^{-1} \mathrm{~K}^{-1}$, which is consistent with the reported results, ${ }^{7,33}$ while the thermal conductivities of $\mathrm{G} / \mathrm{CaCl}_{2} \cdot 6 \mathrm{H}_{2} \mathrm{O}$ and $\mathrm{r}-\mathrm{GO} / \mathrm{CaCl}_{2} \cdot 6 \mathrm{H}_{2} \mathrm{O}$ are $0.64 \mathrm{~W} \mathrm{~m}^{-1} \mathrm{~K}^{-1}$ and $1.01 \mathrm{~W} \mathrm{~m}^{-1} \mathrm{~K}^{-1}$, respectively, which proves that $\mathrm{G}$ and $\mathrm{r}-\mathrm{GO}$ can boost the thermal conductivity of hydrated salts and r-GO has a greater effect than graphite due to its layered and reticular structure. Additionally, the large increase for $\mathrm{r}-\mathrm{GO} / \mathrm{CaCl}_{2} \cdot 6 \mathrm{H}_{2} \mathrm{O}$ is caused by the high thermal conductivity of the r-GO network, in which phonons travel with less resistance. Also, the large interfacial contact area and the strong interface between the PCM and r-GO help to improve the thermal conductivity of $\mathrm{r}-\mathrm{GO} / \mathrm{CaCl}_{2} \cdot 6 \mathrm{H}_{2} \mathrm{O}$.

Theoretically, considering the vast thermal conductivity of graphene, the thermal conductivity of $\mathrm{r}-\mathrm{GO} / \mathrm{CaCl}_{2} \cdot 6 \mathrm{H}_{2} \mathrm{O}$ should give a higher enhancement than the obtained value in this work. However, the structural defects in r-GO reduce the effect of boosting the thermal conductivity of PCMs. ${ }^{21}$ Additionally, the main heat transfer mechanism is attributed to lattice vibrations or phonons in materials, but in prepared r-GO/ $\mathrm{CaCl}_{2} \cdot 6 \mathrm{H}_{2} \mathrm{O}$, weak phonon coupling in the vibrational modes at the $\left(\mathrm{CaCl}_{2} \cdot 6 \mathrm{H}_{2} \mathrm{O}\right)-(\mathrm{PVP})-(\mathrm{r}-\mathrm{GO})$ interfaces causes large thermal resistance, also named the kapitza resistance, which reduces the thermal conductivity of $\mathrm{r}-\mathrm{GO} / \mathrm{CaCl}_{2} \cdot 6 \mathrm{H}_{2} \mathrm{O} .{ }^{34,35}$

\subsection{The thermal properties of PCMs}

Phase change enthalpy is a vital property in PCMs and it can be utilized as an index to evaluate the thermal energy storage capacity of PCMs. Therefore, DSC was performed to test the thermal properties of PCMs with the results shown in Fig. 7 and Table 2. As shown in Table 2, the melting enthalpies are $175.2 \mathrm{~J} \mathrm{~g}^{-1}, 180.6 \mathrm{~J} \mathrm{~g}^{-1}$ and $185.6 \mathrm{~J} \mathrm{~g}^{-1}$ for $\mathrm{G} / \mathrm{CaCl}_{2} \cdot 6 \mathrm{H}_{2} \mathrm{O}, \mathrm{r}-\mathrm{GO} /$

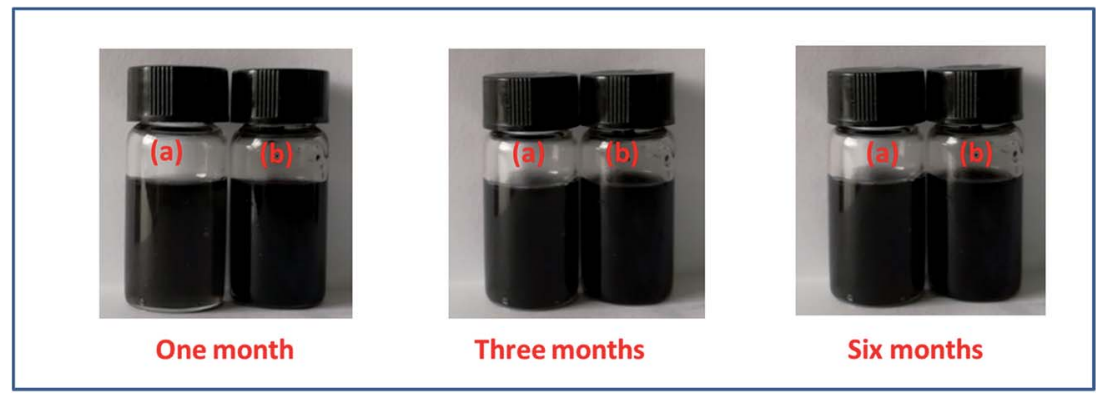

Fig. 3 The dispersing stability of (a) the G aqueous dispersion and (b) the $r-G O$ aqueous dispersion. 


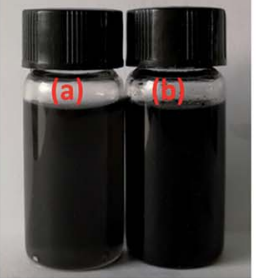

One month

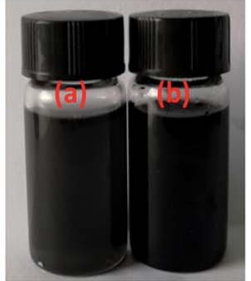

Two months

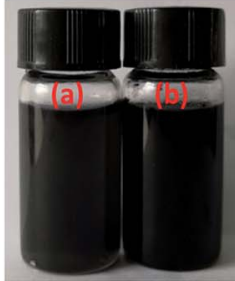

Four months

Fig. 4 The dispersing stability of the additives in (a) $\mathrm{G} / \mathrm{CaCl}_{2} \cdot 6 \mathrm{H}_{2} \mathrm{O}$ and (b) $\mathrm{r}-\mathrm{GO} / \mathrm{CaCl}_{2} \cdot 6 \mathrm{H}_{2} \mathrm{O} P C M s$.

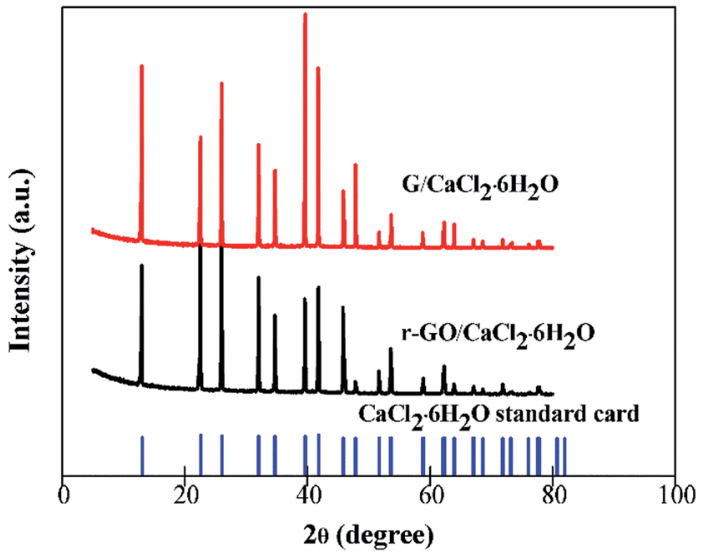

Fig. 5 The XRD patterns of $\mathrm{G} / \mathrm{CaCl}_{2} \cdot 6 \mathrm{H}_{2} \mathrm{O}$ and $\mathrm{r}-\mathrm{GO} / \mathrm{CaCl}_{2} \cdot 6 \mathrm{H}_{2} \mathrm{O}$ PCMs.

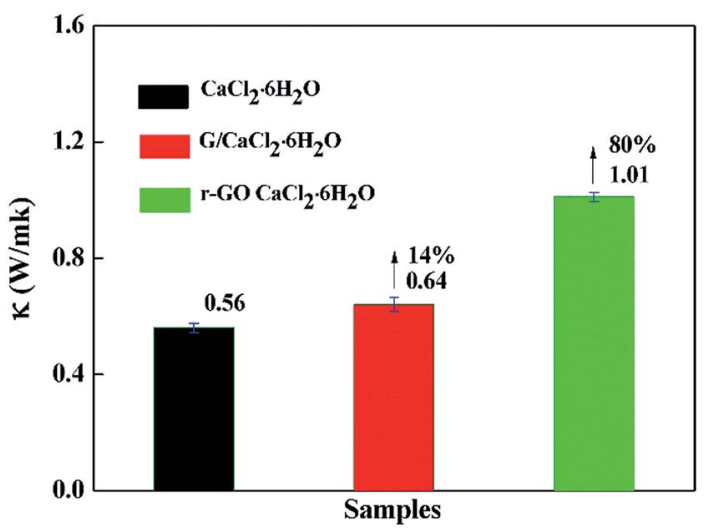

Fig. 6 The thermal conductivities of $\mathrm{CaCl}_{2} \cdot 6 \mathrm{H}_{2} \mathrm{O}, \mathrm{G} / \mathrm{CaCl}_{2} \cdot 6 \mathrm{H}_{2} \mathrm{O}$ and $r-\mathrm{GO} / \mathrm{CaCl}_{2} \cdot 6 \mathrm{H}_{2} \mathrm{O} \mathrm{PCMs}$.

$\mathrm{CaCl}_{2} \cdot 6 \mathrm{H}_{2} \mathrm{O}$ and $\mathrm{CaCl}_{2} \cdot 6 \mathrm{H}_{2} \mathrm{O}$, respectively. The decreased enthalpies are caused by parts of the PCM being replaced by the additives that do not undergo the phase change, and the larger decrease for $\mathrm{G} / \mathrm{CaCl}_{2} \cdot 6 \mathrm{H}_{2} \mathrm{O}$ may be caused by the larger size of graphite preventing the crystallization of $\mathrm{CaCl}_{2} \cdot 6 \mathrm{H}_{2} \mathrm{O}$. In previous cases, adding $\sim 4.5 \%$ of $\mathrm{Al}_{2} \mathrm{O}_{3}$ into hydrated salts leads to a $\sim 61.3 \%$ increase in the thermal conductivity and an $\sim 8 \%$ decrease in the enthalpy, ${ }^{16}$ adding $\sim 0.5 \%$ of nano-Cu into hydrated salt leads to a $\sim 20 \%$ increase in the thermal conductivity and $\mathrm{a} \sim 3.3 \%$ decrease in the enthalpy, ${ }^{15}$ and adding $\sim 5 \%$ of graphite flakes into hydrated salts leads to a $\sim 61 \%$ increase in the thermal conductivity and at least a $\sim 5 \%$ decrease in the enthalpy. ${ }^{17}$ In this work, adding $\sim 0.018 \%$ graphite leads to a $\sim 14 \%$ increase in the thermal conductivity and a $5.6 \%$ decrease in the enthalpy, while adding $\sim 0.018 \%$ r-GO leads to an $\sim 80 \%$ increase in the thermal conductivity and a $\sim 2.7 \%$ decrease in the enthalpy (Fig. 6 and 7). These comparisons with graphite, $\mathrm{r}_{-} \mathrm{Al}_{2} \mathrm{O}_{3}$, nano-Cu and graphite flakes show that utilizing the r-GO aqueous dispersion is a more efficient way to enhance the thermal conductivity of hydrated salt PCMs.

It is also noted that the crystallizing enthalpies of $\mathrm{G} / \mathrm{CaCl}_{2}$ $\cdot 6 \mathrm{H}_{2} \mathrm{O}, \mathrm{r}-\mathrm{GO} / \mathrm{CaCl}_{2} \cdot 6 \mathrm{H}_{2} \mathrm{O}$ and $\mathrm{CaCl}_{2} \cdot 6 \mathrm{H}_{2} \mathrm{O}$ are $140.4 \mathrm{~J} \mathrm{~g}^{-1}, 153.7$ $\mathrm{J} \mathrm{g}^{-1}$, and $161.8 \mathrm{~J} \mathrm{~g}^{-1}$, respectively, which are lower than the melting enthalpies mentioned above. This may be attributed to the special crystallizing process of $\mathrm{CaCl}_{2} \cdot 6 \mathrm{H}_{2} \mathrm{O}$ which has two steps, with the first being formation of $\mathrm{CaCl}_{2} \cdot 4 \mathrm{H}_{2} \mathrm{O}$ and the second being peritectic reaction of the mixture. These two steps can also be observed from the phase diagram of $\mathrm{CaCl}_{2}-\mathrm{H}_{2} \mathrm{O}$. ${ }^{36}$ The step of formation of $\mathrm{CaCl}_{2} \cdot 4 \mathrm{H}_{2} \mathrm{O}$ is a metastable state with a fast change of enthalpy that the DSC instrument may not be sensitive enough to detect, as there is no peak for the first step of crystallization in the DSC curves. ${ }^{37}$

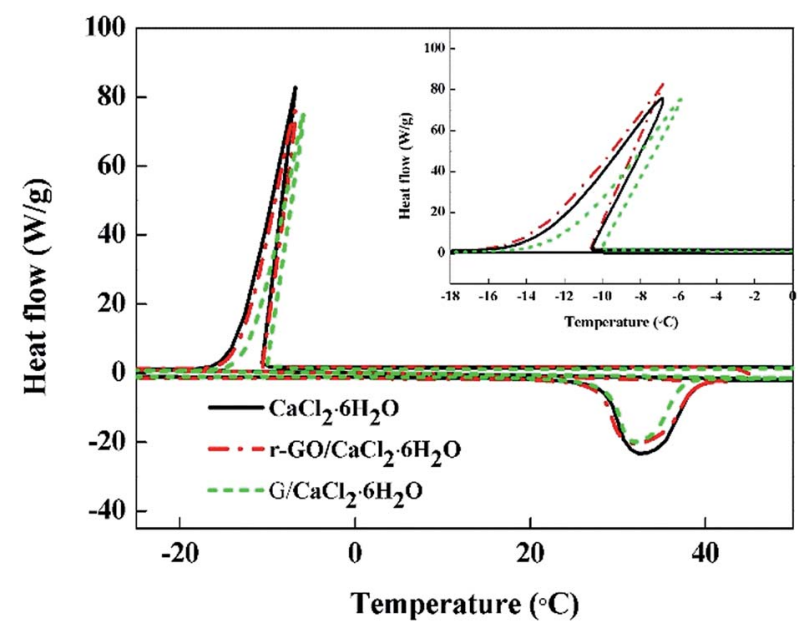

Fig. 7 The DSC curves of $\mathrm{CaCl}_{2} \cdot 6 \mathrm{H}_{2} \mathrm{O}, \mathrm{G} / \mathrm{CaCl}_{2} \cdot 6 \mathrm{H}_{2} \mathrm{O}$ and $\mathrm{r}-\mathrm{GO} /$ $\mathrm{CaCl}_{2} \cdot 6 \mathrm{H}_{2} \mathrm{O}$ PCMs. 
Table 2 The thermal properties of $\mathrm{G} / \mathrm{CaCl}_{2} \cdot 6 \mathrm{H}_{2} \mathrm{O}, \mathrm{r}-\mathrm{GO} / \mathrm{CaCl}_{2} \cdot 6 \mathrm{H}_{2} \mathrm{O}$ and $\mathrm{CaCl}_{2} \cdot 6 \mathrm{H}_{2} \mathrm{O}$

\begin{tabular}{lllll}
\hline Sample & $\begin{array}{l}\text { Melting enthalpy } \\
\left(\mathrm{J} \mathrm{g}^{-1}\right)\end{array}$ & $\begin{array}{l}\text { Crystallizing } \\
\text { enthalpy }\left(\mathrm{J} \mathrm{g}^{-1}\right)\end{array}$ & $\begin{array}{l}\text { Melting temperature } \\
\left({ }^{\circ} \mathrm{C}\right)\end{array}$ & $\begin{array}{l}\text { Crystallizing } \\
\text { temperature }\left({ }^{\circ} \mathrm{C}\right)\end{array}$ \\
\hline $\mathrm{CaCl}_{2} \cdot 6 \mathrm{H}_{2} \mathrm{O}$ & 185.6 & 161.8 & 28.4 & -10.5 \\
$\mathrm{r}-\mathrm{GO} / \mathrm{CaCl}_{2} \cdot 6 \mathrm{H}_{2} \mathrm{O}$ & 180.6 & 153.7 & 27.8 & -10.4 \\
$\mathrm{G} / \mathrm{CaCl}_{2} \cdot 6 \mathrm{H}_{2} \mathrm{O}$ & 175.2 & 140.4 & 28.5 & -10.1
\end{tabular}

Additionally, the crystallizing temperatures of PCMs do not change significantly, with $-10.1{ }^{\circ} \mathrm{C},-10.4{ }^{\circ} \mathrm{C}$ and $-10.5{ }^{\circ} \mathrm{C}$ for $\mathrm{G} / \mathrm{CaCl}_{2} \cdot 6 \mathrm{H}_{2} \mathrm{O}, \mathrm{r}-\mathrm{GO} / \mathrm{CaCl}_{2} \cdot 6 \mathrm{H}_{2} \mathrm{O}$ and $\mathrm{CaCl}_{2} \cdot 6 \mathrm{H}_{2} \mathrm{O}$, respectively. This indicates that the particles have no influence on the crystallizing temperature of hydrated salts, which may be attributed to the sizes and the morphologies of particles used in this work that do not match the crystal type of $\mathrm{CaCl}_{2} \cdot 6 \mathrm{H}_{2} \mathrm{O} .{ }^{38}$

\subsection{Thermal stability of the $\mathrm{r}-\mathrm{GO} / \mathrm{CaCl}_{2} \cdot 6 \mathrm{H}_{2} \mathrm{O} \mathrm{PCM}$}

Thermal stability can be used as a measure to evaluate the adaptive ability of temperature changes in applications. For hydrated salts, the loss of crystal water is a key issue to reduce the heat storage capacity in cycling. The viscosity of the liquid state is an important property to sustain the stability of the system, and high viscosity has the function of inhibiting movement of the water molecules from the liquid system to the environment in the process of a phase change. Therefore, the viscosities of the PCM systems were tested and the results are shown in Fig. 8(a). As shown in Fig. 8(a), the viscosity of r-GO/ $\mathrm{CaCl}_{2} \cdot 6 \mathrm{H}_{2} \mathrm{O}$ is improved to $59.6 \mathrm{mpa} \mathrm{s}$ from $41.6 \mathrm{mpa} \mathrm{s}$ (for $\mathrm{CaCl}_{2} \cdot 6 \mathrm{H}_{2} \mathrm{O}$ ) due to the effect of PVP and the uniform dispersion of r-GO in the PCM system.

Then, TGA analysis was performed to test the stability of the PCM under continuous heating conditions. Fig. 8(b) shows the entire TGA analysis curve of both $\mathrm{r}-\mathrm{GO} / \mathrm{CaCl}_{2} \cdot 6 \mathrm{H}_{2} \mathrm{O}$ and $\mathrm{CaCl}_{2}$ $\cdot 6 \mathrm{H}_{2} \mathrm{O}$. The mass loss ending temperature of $\mathrm{r}-\mathrm{GO} / \mathrm{CaCl}_{2} \cdot 6 \mathrm{H}_{2} \mathrm{O}$ is $167^{\circ} \mathrm{C}$ which is higher than that of $\mathrm{CaCl}_{2} \cdot 6 \mathrm{H}_{2} \mathrm{O}\left(145^{\circ} \mathrm{C}\right)$, and the remaining mass for both PCMs reaches about $49.3 \%$ which is lower than the theoretical mass fraction of $\mathrm{CaCl}_{2}$ in $\mathrm{CaCl}_{2} \cdot 6 \mathrm{H}_{2} \mathrm{O}$ $(50.6 \%)$ due to the surface water on the hydrated salt crystal. Additionally, the temperatures of the maximum rate of weight loss of $\mathrm{r}-\mathrm{GO} / \mathrm{CaCl}_{2} \cdot 6 \mathrm{H}_{2} \mathrm{O}$ at different stages are $57.3^{\circ} \mathrm{C}$ and $157.0{ }^{\circ} \mathrm{C}$, which are higher than $56.3{ }^{\circ} \mathrm{C}$ and $119.0{ }^{\circ} \mathrm{C}\left(\right.$ for $\mathrm{CaCl}_{2} \cdot 6 \mathrm{H}_{2} \mathrm{O}$ ) as shown by the differential curves of mass loss in Fig. $8(\mathrm{~b})$. These results indicate that the prepared $\mathrm{r}-\mathrm{GO} / \mathrm{CaCl}_{2} \cdot 6 \mathrm{H}_{2} \mathrm{O}$ is a more stable system than $\mathrm{CaCl}_{2} \cdot 6 \mathrm{H}_{2} \mathrm{O}$ over changing temperature.

\subsection{The thermal reliability of $\mathrm{r}-\mathrm{GO} / \mathrm{CaCl}_{2} \cdot 6 \mathrm{H}_{2} \mathrm{O}$}

The thermal reliability of PCMs is an essential property for the achievement of economic value, and long operating cycles of PCMs can enhance efficiency and reduce the costs of operation and maintenance of the energy system. Therefore, a test of 100 cycles was conducted using DSC analysis to investigate the thermal reliability of the samples, and the results are shown in Fig. 9. After 100 cycles, the melting and crystallizing enthalpies of $\mathrm{r}-\mathrm{GO} / \mathrm{CaCl}_{2} \cdot 6 \mathrm{H}_{2} \mathrm{O}$ decreased to $178.4 \mathrm{~J} \mathrm{~g}^{-1}$ and $150.7 \mathrm{~J} \mathrm{~g}^{-1}$ from $180.6 \mathrm{~J} \mathrm{~g}^{-1}$ and $153.7 \mathrm{~J} \mathrm{~g}^{-1}$, dropping by $1.2 \%$ and $2.0 \%$, respectively, while those of $\mathrm{CaCl}_{2} \cdot 6 \mathrm{H}_{2} \mathrm{O}$ decreased to $178.9 \mathrm{~J} \mathrm{~g}^{-1}$ and $147.8 \mathrm{~J} \mathrm{~g}^{-1}$ from $185.6 \mathrm{~J} \mathrm{~g}^{-1}$ and $161.8 \mathrm{~J} \mathrm{~g}^{-1}$, dropping by $3.7 \%$ and $8.7 \%$, respectively. Apart from the instrument error, testing errors are also caused by the tiny testing sample size for the DSC instrument. ${ }^{39}$ These data show that the proportions of enthalpy reduction of the $\mathrm{r}-\mathrm{GO} / \mathrm{CaCl}_{2} \cdot 6 \mathrm{H}_{2} \mathrm{O}$ system are lower than those of $\mathrm{CaCl}_{2} \cdot 6 \mathrm{H}_{2} \mathrm{O}$, suggesting that the $\mathrm{r}-\mathrm{GO} / \mathrm{CaCl}_{2}$ $\cdot 6 \mathrm{H}_{2} \mathrm{O}$ system shows better reliability due to the improvement of viscosity. Additionally, the melting temperatures do not show significant changes, and the crystallizing temperatures of $\mathrm{r}-\mathrm{GO} /$ $\mathrm{CaCl}_{2} \cdot 6 \mathrm{H}_{2} \mathrm{O}$ have more widely varying values with a minimum of $-14.8^{\circ} \mathrm{C}$ and a maximum of $-10.4{ }^{\circ} \mathrm{C}$, compared to $-10.5^{\circ} \mathrm{C}$ and $-9.5{ }^{\circ} \mathrm{C}$ for $\mathrm{CaCl}_{2} \cdot 6 \mathrm{H}_{2} \mathrm{O}$. This is the main drawback of adding additives, as they change their distribution slightly in the system in long cycles and further influence the susceptible crystallizing temperature. This drawback also increases the testing errors of crystallizing temperatures in the cycling of the
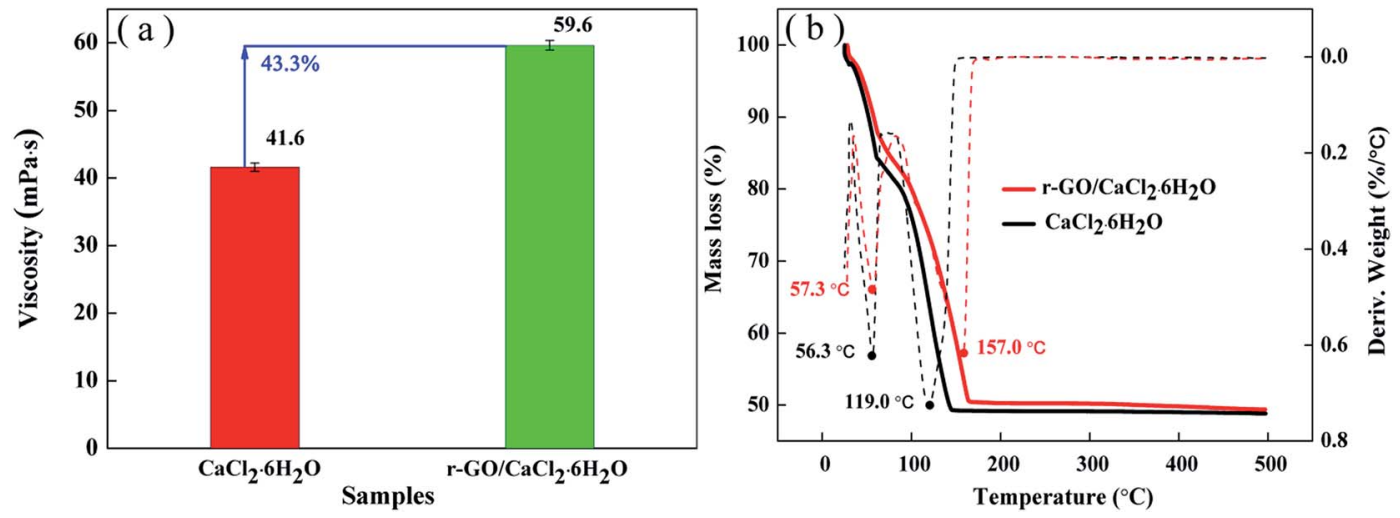

Fig. 8 (a) The viscosities and (b) TGA curves of $\mathrm{CaCl}_{2} \cdot 6 \mathrm{H}_{2} \mathrm{O}$ and $r-\mathrm{GO} / \mathrm{CaCl}_{2} \cdot 6 \mathrm{H}_{2} \mathrm{O} P C M s$. 

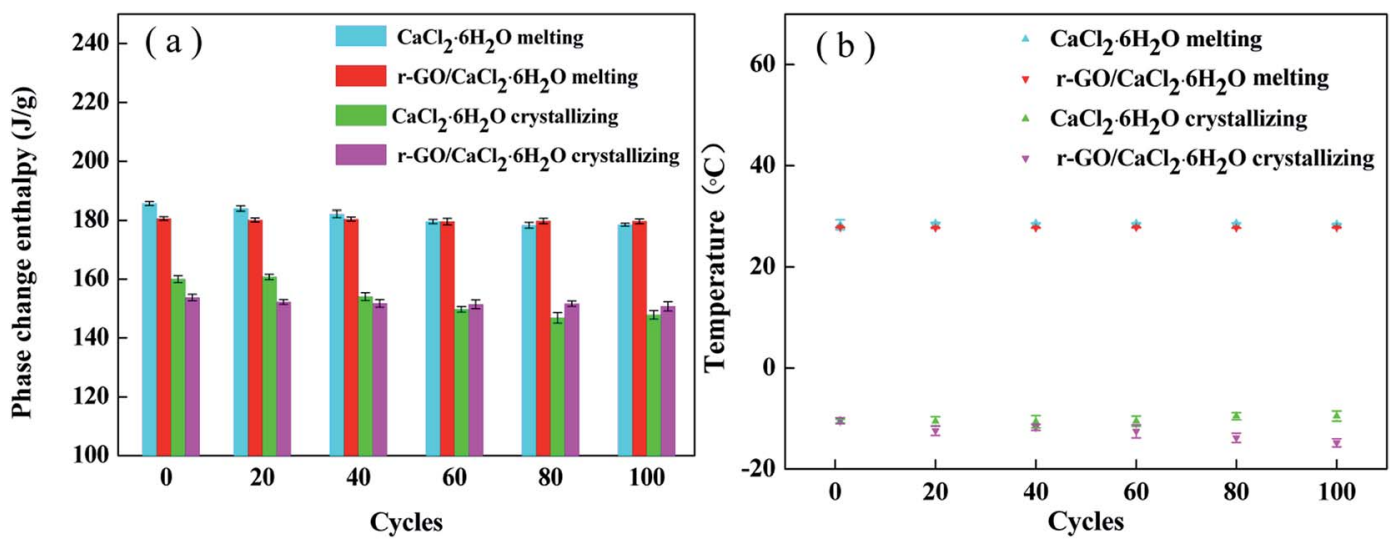

Fig. 9 The thermal properties of $\mathrm{CaCl}_{2} \cdot 6 \mathrm{H}_{2} \mathrm{O}$ and $r-\mathrm{GO} / \mathrm{CaCl}_{2} \cdot 6 \mathrm{H}_{2} \mathrm{O}$ after different cycles: (a) the phase change enthalpy and (b) the phase change temperature.

$\mathrm{r}-\mathrm{GO} / \mathrm{CaCl}_{2} \cdot 6 \mathrm{H}_{2} \mathrm{O}$ system shown in the error bars. Therefore, further studies are required to solve this problem for adding functional additives.

\section{Conclusions}

It is shown that preparing a hydrated salt PCM system by combining the r-GO aqueous dispersion and the salt is an efficient way to utilize the high thermal conductivity of graphene derivatives. The well-dispersed r-GO has a great effect in boosting the thermal conductivity without causing a large enthalpy reduction in the hydrated salts. $\sim 0.018 \%$ (by weight) of r-GO increases the thermal conductivity by $\sim 80 \%$ and gives a $\sim 2.7 \%$ decrease in enthalpy, while the same amount of graphite incurs a $\sim 14 \%$ increase in thermal conductivity and a $\sim 5.6 \%$ decrease in enthalpy, and the performance of r-GO is also superior to other thermal additives reported in previous literature. Additionally, the well-dispersed r-GO and the surface active agent for dispersing r-GO can help to enhance the stability and reliability of the hydrated salt systems. The decomposing temperatures of $\mathrm{r}-\mathrm{GO} / \mathrm{CaCl}_{2} \cdot 6 \mathrm{H}_{2} \mathrm{O}$ are higher than those of $\mathrm{CaCl}_{2} \cdot 6 \mathrm{H}_{2} \mathrm{O}$. After 100 cycles, the melting enthalpy of $\mathrm{r}-\mathrm{GO} / \mathrm{CaCl}_{2} \cdot 6 \mathrm{H}_{2} \mathrm{O}$ decreases to $178.4 \mathrm{~J} \mathrm{~g}^{-1}$ from $180.6 \mathrm{~J} \mathrm{~g}^{-1}$, only dropping by $1.2 \%$, while that of $\mathrm{CaCl}_{2} \cdot 6 \mathrm{H}_{2} \mathrm{O}$ decreases to $178.9 \mathrm{~J} \mathrm{~g}^{-1}$ from $185.6 \mathrm{~J} \mathrm{~g}^{-1}$, dropping by $3.7 \%$. These results indicate that utilizing the r-GO aqueous dispersion has advantages to improve the thermal properties of hydrated salts including thermal conductivity, thermal stability and reliability without a significant reduction of the enthalpy. Additionally, the method used in this work can be applied to other functional additive materials which cannot be directly dispersed well into hydrated salt PCMs, and it is applicable in hydrated salt phase change material systems for the modification of thermal properties.

\section{Conflicts of interest}

The authors have declared no conflicts of interest.

\section{Acknowledgements}

Financial support from the Natural Science Foundation of Qinghai province of China (No. 2017-ZJ-938Q), Qinghai Provincial Thousand Talents Program for High-level Innovative Professionals, and Major Science and Technology Projects of Qinghai Province of China (No. 2015-GX-A1A) is gratefully acknowledged.

\section{References}

1 J. H. VanZwieten, L. T. Rauchenstein and L. Lee, Renewable Sustainable Energy Rev., 2017, 75, 683-691.

2 P. Ziolkowski, T. Kowalczyk, S. Kornet and J. Badur, Energy Convers. Manage., 2017, 146, 158-173.

3 S. Liu and H. Yang, RSC Adv., 2016, 6, 48033-48042.

4 B. Tan, Z. Huang, Z. Yin, X. Min, Y. g. Liu, X. Wu and M. Fang, RSC Adv., 2016, 6, 15821-15830.

5 J. Tang, S. Fan, W. Dong, J. Wang, H. Gao, M. Yang, M. Yang and G. Wang, RSC Adv., 2016, 6, 44807-44813.

6 D. Fang, X. M. Cheng, Y. Y. Li and Z. Sun, $R S C A d v$., 2016, 6, 96327-96333.

7 M. Kenisarin and K. Mahkamov, Sol. Energy Mater. Sol. Cells, 2016, 145, 255-286.

8 D. Buddhi and V. V. Tyagi, Renewable Sustainable Energy Rev., 2007, 11, 1146-1166.

9 A. Efimova, S. Pinnau, M. Mischke, C. Breitkopf, M. Ruck and P. Schmidt, Thermochim. Acta, 2014, 575, 276-278.

10 L. Nkhonjera, T. Bello-Ochende, G. John and C. K. King'ondu, Renewable Sustainable Energy Rev., 2017, 75, 157-167.

11 L. Liu, D. Su, Y. Tang and G. Fang, Renewable Sustainable Energy Rev., 2016, 62, 305-317.

12 M. Pomianowski, P. Heiselberg and Y. Zhang, Energy Build., 2013, 67, 56-69.

13 Z. j. Duan, H. z. Zhang, L. x. Sun, Z. Cao, F. Xu, Y. j. Zou, H. l. Chu, S. j. Qiu, C. l. Xiang and H. y. Zhou, J. Therm. Anal. Calorim., 2013, 115, 111-117. 
14 X. Li, Y. Zhou, H. Nian, X. Ren, O. Dong, C. Hai, Y. Shen and J. Zeng, Appl. Therm. Eng., 2016, 102, 38-44.

15 W. Cui, Y. Yuan, L. Sun, X. Cao and X. Yang, Renewable Energy, 2016, 99, 1029-1037.

16 Y. Liu and Y. Yang, Sol. Energy Mater. Sol. Cells, 2017, 160, 18-25.

17 M. Dannemand, J. B. Johansen and S. Furbo, Sol. Energy Mater. Sol. Cells, 2016, 145, 287-295.

18 A. A. Balandin, S. Ghosh, W. Z. Bao, I. Calizo, D. Teweldebrhan, F. Miao and C. N. Lau, Nano Lett., 2008, 8, 902-907.

19 M. Lotya, Y. Hernandez, P. J. King, R. J. Smith, V. Nicolosi, L. S. Karlsson, F. M. Blighe, S. De, Z. M. Wang, I. T. McGovern, G. S. Duesberg and J. N. Coleman, J. Am. Chem. Soc., 2009, 131, 3611-3620.

20 S. B. Son, F. Huang, T. S. Bae and W. K. Hong, J. Alloys Compd., 2017, 698, 384-389.

21 D. Yang, A. Velamakanni, G. Bozoklu, S. Park, M. Stoller, R. D. Piner, S. Stankovich, I. Jung, D. A. Field, C. A. Ventrice and R. S. Ruoff, Carbon, 2009, 47, 145-152.

22 A. Bagri, C. Mattevi, M. Acik, Y. J. Chabal, M. Chhowalla and V. B. Shenoy, Nat. Chem., 2010, 2, 581-587.

23 W. Park, J. N. Hu, L. A. Jauregui, X. L. Ruan and Y. P. Chen, Appl. Phys. Lett., 2014, 104, 4.

24 L. B. Xu, G. F. Chen, W. Wang, L. Li and X. Z. Fang, Composites, Part A, 2016, 84, 472-481.

25 N. Zhao, X. N. Cheng, J. Yang, M. X. Yang, S. H. Zheng and Y. Z. Zhou, J. Phys. Chem. Solids, 2014, 75, 1141-1146.
26 H. Y. He, J. Klinowski, M. Forster and A. Lerf, Chem. Phys. Lett., 1998, 287, 53-56.

27 X. Z. Zhou, G. Lu, X. Y. Qi, S. X. Wu, H. Li, F. Boey and H. Zhang, J. Phys. Chem. C, 2009, 113, 19119-19122.

28 K. S. Vasu, B. Chakraborty, S. Sampath and A. K. Sood, Solid State Commun., 2010, 150, 1295-1298.

29 J. Robertson, Mater. Sci. Eng., R, 2002, 37, 129-281.

30 K. Krishnamoorthy, M. Veerapandian, R. Mohan and S.-J. Kim, Appl. Phys. A, 2011, 106, 501-506.

31 M. S. Dresselhaus, A. Jorio, M. Hofmann, G. Dresselhaus and R. Saito, Nano Lett., 2010, 10, 751-758.

32 Y. Shen, Y. Zhou, Y. Sun, L. Zhang, Y. Wang, J. Hu and Y. Zhang, Appl. Surf. Sci., 2017, 412, 497-504.

33 R. Nikolic and J. Tripkovic, Appl. Phys. A: Mater. Sci. Process., 1987, 44, 293-297.

34 S. Shenogin, L. Xue, R. Ozisik, P. Keblinski and D. G. Cahill, J. Appl. Phys., 2004, 95, 8136-8144.

35 H. Zhong and J. R. Lukes, Phys. Rev. B: Condens. Matter Mater. Phys., 2006, 74, 125403.

36 O. Dong, D. Zeng, H. Zhou, H. Han, X. Yin and Y. Du, Calphad, 2011, 35, 269-275.

37 H. Stymne, G. Wettermark and B. Carlsson, Sol. Energy, 1979, 23(4), 342-350.

38 G. A. Lane, Sol. Energy Mater. Sol. Cells, 1992, 27, 135-160.

39 G. H. Feng, K. L. Huang, H. L. Xie, H. X. Li, X. Liu, S. B. Liu and C. H. Cao, Renewable Energy, 2016, 87, 1148-1153. 